\title{
LAMENTATIONS IN THE ENGLISH BIBLE TRANSLATION TRADITION OF THE KING JAMES BIBLE (1611)
}

\author{
Jacobus A Naudé \& Cynthia L Miller-Naudé \\ Department of Classical and Near Eastern Studies \\ University of the Free State ${ }^{1}$
}

\begin{abstract}
This article examines how the translators of the King James Bible (1611) appropriated much of the wording from the prior tradition of the Bible in English (especially the Tyndale New Testament of 1526, the Coverdale Bible of 1535, the Matthew's Bible of 1537, the Great Bible of 1539, the Geneva Bible of 1539, and the Bishops' Bible of 1568), but also diverged from that tradition in specific ways and for specific purposes. Furthermore, by analyzing a selection of the marginal notes, it will be shown how they were constructed to serve as subtle but powerful tools for mediating between conflicting theological views and uniting religious parties around a single English Bible. The King James Version translators accepted only a small fraction of the marginal notes that were used in some previous English translations. By utilising a technique of keeping silent about contemporary issues and instead focusing on the basic principles of translation, the King James Version translators used the metatextual marginal notes to regulate the reader's mental preparation for a translation which diverges from the accepted sectarian interpretations in order to ensure that broader, non-sectarian interpretations will be considered orthodox. In this respect, the King James translation adopted a stance toward both metatext and translation strategy that was diametrically opposed to that of the Geneva Bible, even though much of the specific wording of the King James Version was drawn from the Geneva Bible.
\end{abstract}

Key Words: Bible Translation, Lamentations, King James Bible, Geneva Bible, Metatexts

\section{Introduction}

The translators of the King James Bible (1611) made extensive use of previous English translations made periodically during the previous century. Chief among these were the translation of the New Testament published by William Tyndale in 1526, the first complete Bible in English produced in 1535 by Myles Coverdale, the Matthew's Bible (1537) published by John Rogers, the Great Bible (1539), the Geneva Bible (1560) and the Bishops' Bible (1568). The aim of the King James translators was the production of an accurate translation which could mediate between conflicting theological views and unite religious parties around a single English Bible.

The authors wish to express their thanks to their assistants, Gladys Gelderbloem and Jackie Smith for their assistance in the technical matters of this article. 
Any specific translational choice cannot be treated as random but rather as embedded in, and contributing to, the elaboration of a concrete social reality. Structures of anticipation (or, frames) can be created that guide the interpretation of these choices. According to Baker, processes of framing can draw on practically any linguistic or non-linguistic resource to set up an interpretive context for the reader or listener. ${ }^{2}$ In translations, these may include exploiting metalinguistic or paralinguistic devices that create a frame to guide the reader in interpreting the translation such as the titles of books/chapters and marginal notes. Metatexts can provide an important overview of the ideological context of the translation and of the expectations of the readers. ${ }^{3}$ Translators often defend themselves and their translations by utilising metatexts to (re)frame the translations of sacred texts and to narrate the nature of the specific translation. ${ }^{4}$

In this article the focus will be on Lamentations in the English Bible translation tradition of the King James Bible (1611). It will be shown that the King James translators appropriated much of the wording from the English Bible translation tradition, but that they diverged from that tradition in specific ways and for specific purposes. Furthermore, by analyzing a selection of the marginal notes, it will be shown how they were constructed to serve as subtle but powerful tools for mediating between conflicting theological views and uniting religious parties around a single English Bible. The King James Version translators accepted only a small fraction of the marginal notes that were used in some previous English translations. By utilising a technique of keeping silent about contemporary issues and instead focusing on the basic principles of translation, the King James Version translators used the metatextual marginal notes to regulate the reader's mental preparation for a translation which diverges from the accepted sectarian interpretations in order to ensure that broader, non-sectarian interpretations will be considered orthodox. In this respect, the King James translation adopted a stance toward both metatext and translation strategy that was diametrically opposed to that of the Geneva Bible, even though much of the specific wording of the King James Version was drawn from the Geneva Bible. ${ }^{5}$

The outline of the paper is as follows: the exposition begins with a few statements about the background of English Bible translations as a source of religious division, followed by an overview of the translation tradition on macro and microlevel, and an analysis of the marginal notes.

\section{The English Bible Translations as a Source of Religious Division}

When James VI of Scotland became James I of England in 1603, the Elizabethan era (15581603) was just ending. The pre-Jacobean period was not only shaped by the struggles between monarchy and democracy, the balancing of tolerance and intolerance, and the separation of Protestant and Roman Catholic, but also internal battles within Protestantism. The Puritans were loyal to the crown but wanted even more distance from Rome. The

M Baker, Translation and Conflict: A Narrative Account (London and New York: Routledge, 2006).

See CH Eliot (ed.), Prefaces and Prologues to Famous Books (New York: PF Collier \& Sons, 1910/1969), 3-4; and A Gray (ed.), The Book of Prefaces (London and New York: Bloomsbury Publishing, 2002), 7-11.

4 For example, the Aristeas Letter served as a metatext for the Septuagint (LXX) and St. Jerome's Letter to Pammachius served as a metatext for the Vulgate. See JA Naudé, "The Role of Metatexts in the Translations of Sacred Texts: The Case of the Aristeas Book and the Septuagint", VTSup 261 (2009):281-98.

5 For an extensive treatment of the metatexts of the King James Bible and their functions, see JA Naudé, "The Role of Metatexts in the King James Version as a Means of Mediating Conflicting Theological Views" (unpublished paper presented at the symposium "The KJV at 400: Assessing its Genius as Bible Translation and its Literary Influence,” Society of Biblical Literature annual meeting, November 19, 2011). 
Presbyterians were Puritans who were ready to do away with the hierarchical structure of powerful bishops. The Pilgrims, including Nonconformists and Separatists, wanted the state out of church affairs. All of these Protestant groups opposed the Church of England bishops (the Prayer Book Defenders or the Protestant Hierarchy). ${ }^{6}$

The text of the Bible was a source of division among religious parties in England rather than a bond of unity. ${ }^{7}$ Although the Bishops' Bible (in print 1568-1617), translated under the direction of Matthew Parker, Archbishop of Canterbury, was the official version of the established church, the Puritan's Geneva version (in print 1560-1644) enjoyed broad popularity as the most widely read Bible of the Elizabethan era and subsequently of the Jacobean era. The Geneva Bible was the production of exiles who fled England for refuge within the Protestant havens of Europe in the first years of Mary Tudor's reign. It broke new ground and set new standards in biblical translation, illustration, and layout. Its numerous features - such as the marginal comments - propelled it to the forefront of English Bible translations and it was the undisputed market leader. The Great Bible (in print 1539-1569) and its officially sanctioned successors were powerless to meet the challenge posed by the Geneva Bible, which was the product of private enterprise and religious enthusiasm on the part of a small group of English Protestant exiles in the city of Geneva. ${ }^{8}$ It offered comments on the text, which often expressed the radical Protestant ideas associated with Geneva at this time. Meanwhile the translation of the Bible used in the Anglican Book of Common Prayer (1549, revised 1552, 1559) was under criticism for its inaccuracies. In addition, with their persecution under Elizabeth, the Catholics felt the need for their own translation to counter the increasingly popular Protestant editions. Roman Catholic scholars who had fled to the continent published the Rheims-Douai New Testament in 1582 and the Old Testament in 1609. Its reception in England was comparable to that of the Tyndale New Testament. Copies were burnt and its owners, usually priests, were imprisoned and tortured. ${ }^{9}$ These tensions between Anglicans and Puritans (who insisted that the Reformation in England did not go far enough and that the Church of England retained too many Catholic elements), on the one hand, and Catholics, on the other hand, could have torn England apart had they been handled badly.

The announcement that James VI of Scotland was to succeed Elizabeth caused undisguised delight in Puritan circles in England. James had been baptized a Catholic and crowned king of Scotland as a Protestant (John Knox preached at his coronation) when he was 13 months old. He was raised by neither his mother nor father, but only by regents, since his mother Mary Queen of Scots was forced to abdicate and was imprisoned. His regents played critical roles in his upbringing. From a very early age, he learned Latin and Greek. He read prolifically and became an articulate intellectual leader. He was selected by Elizabeth I of England, who had no offspring, to succeed her as king of England. His education and experience, having already been the king of Scotland, boded well for him. Yet the reality of the situation was very different. James disliked Presbyterianism and, believing

6 W Barnstone, The Poetics of Translation: History, Theory, Practice. New Haven and London: Yale University Press, 1993:197-216.

SL Greenslade, "The English Versions of the Bible, 1525-1611", in SL Greenslade (ed.), The Cambridge History of the Bible. III. The West from the Reformation to the Present Day (Cambridge: Cambridge University Press, 1975/1987), 141-68; see also AK Curtis, "The Hampton Court Conference", in D Burke (ed.), Translation That Openeth the Window. Reflections on the History and Legacy of the King James Bible. Atlanta: Society of Biblical Literature, 2009:57-71.

8 Barnstone, The Poetics of Translation, 209; A McGrath, In the Beginning: The Story of the King James Bible and How It Changed a Nation, a Language, and a Culture. New York: Doubleday, 2001:98.

9 Barnstone, The Poetics of Translation, 209-210. 
passionately that his royal authority was dependent upon bishops, he lobbied for the retention of episcopal governance of the church. ${ }^{10}$

In order to reconcile the differences of the various religious parties, the king called for a conference at Hampton Court in January 1604. ${ }^{11}$ He took complete control of managing that meeting with both the Anglican bishops and the Puritans. After much inconclusive debate, Dr John Reynolds of Oxford and a spokesperson for the Puritan group, suggested making a new translation that could be approved by the whole church. Aware of the importance of maintaining religious peace, James decided to make at least some conciliatory gesture by commissioning a new Bible translation, thereby surprising the bishops and delighting the Puritans by the strength and direction he gave this matter. His goal was to unite the religious factions around a common English Bible. He accomplished a measure of religious unity directly and immediately with the composition of the translation teams (established in six 'companies': two at Oxford, two at Cambridge, and two at Westminster) and the setting up of the translation process with each group reviewing the other. ${ }^{12}$ The translation brief for the companies was not merely to work together but to produce a Bible of solid academic standards, closely controlled by the Hebrew and Greek texts, and one that could be read in the churches. The use of teams of individuals is one of the King James Version's innovations in translation. The teams were given 15 rules, possibly drafted by Bishop Richard Bancroft but certainly supervised by James. Most of these rules were followed, as can be seen in the 1618 eight-point summary by Samuel Ward, one of the translators, for the Synod of Dort with respect to the Dutch Statevertaling

of 1639. The rules stated the necessity of using the Hebrew and Greek originals. This dependence on Hebrew and Greek originals, as opposed to the Latin, generated the debates between Catholic and Protestant and, in fact, drew the Puritans and Anglicans closer together. The scholarly credentials of the King James version were not doubted, because the companies could command 'any learned man in the land' to respond to questions they could not answer. However, it took decades for the King James Version to displace the Geneva Version in popular acceptance. As late as 1659 the Reverend Dr Robert Gell, minister of the parish of St Mary, Alder-Mary, London, published an 800-page treatise denouncing it and discussing its faults in detail, counting among them a denial of Christ's authority.

Political as well as religious unity was to be achieved through the person of the monarch and through a single version of the Bible, issued with royal authority. This ideology was promoted by the visual statement of the king (Henry VIII) giving the Bible to his people as depicted on the title page of the Great Bible (1539) in the artwork by Hans Holbein (the first 'authorised' version). The image projected is that of a unified nation, united under the monarch and the Bible, in which church and state work harmoniously together. The church upholds the monarchy and the monarchy defends true religion. It is an icon of a godly state and church under their supreme head, who in turn acknowledges his obligations to God,

10 McGrath, In the Beginning, 139.

11 Herbert describes the editio princeps of the King James Version and provides a summary of the commissioning, translation process and production of the King James Version with extant examples in various collections (AS Herbert, Historical Catalogue of Printed Editions of the English Bible 1525-1961. London: The British and Foreign Bible Society; New York: American Bible Society, 1968:130-33, 136-39.

12 It strikingly recalls the circumstance and practice of the seventy-two interpreters of the Septuagint in their monastic quarters on Pharos. See Barnstone, The Poetics of Translation, 214. 
expressed in the Bible. The social ordering of England was thus affirmed every time the Great Bible was opened on a church lectern. ${ }^{13}$

This view of the authority of the monarch is supported by other cases. While in Basel, John Calvin wrote The Institutes of the Christian Religion, dedicated to the king of France, in which he set out clearly the main ideas of the French Reformation. ${ }^{14}$ It was published in Latin in May 1536. By using the authority of the king, Calvin's intention was both to refute his many critics within France, and to set out clearly and attractively the leading themes of Protestant theology.

Other English Bible translations also situated themselves with respect to the monarchy. With a sense of political savvy, Miles Coverdale cultivated support from the royal family as powerful protectors of his Bible translation (1535). It includes an elaborate dedication to King Henry VIII. ${ }^{15}$ The dedication cites Henry's second wife, Anne (Boleyn), who had long supported Coverdale's work on the Bible. After Henry's divorce from Anne and her eventual execution, surviving copies show a correction of 'Anne' to 'Jane' (Seymour), Henry's third wife. However, her arrest and execution prevented the king from officially authorizing the Bible she had supported. ${ }^{16}$

Aware of the importance of the religious reforms introduced by Elizabeth I, William Whittingham (c. 1524-79), the leading translator of the Geneva Bible (1560) and John Calvin's brother-in-law, included a dedicatory epistle to the English monarch, praising her explicitly for her many religious virtues. The none-too-subtle subtext of this dedicatory epistle could hardly be missed: Whittingham wanted his translation to be the Bible of choice for use in churches, to be the people's Bible. A portrait of Elizabeth I also adorned the title page of the Bishop's Bible (1568). ${ }^{17}$ The two translations thus both appealed to the monarch for support and endorsement.

The purpose of the translators as described in the preface was in effect to take up the mantle of Tyndale who produced the first printed English Bible of 1535 and its further modifications in various other translations - Matthew's Bible (1537), Taverner's Bible and the Great Bible (1539), the Geneva Bible (1560), and the Bishop's Bible (1568). The translators were instructed to start with the Bishop's Bible, and to test it carefully against earlier English translations, and especially against the text in its original languages. To this end they made use of all the resources available to them: linguistic tools, ancient as well as modern Bible versions and commentaries, especially noting the resources available in the Spanish, French, Italian and German ('Dutch') languages.

\section{The Translation Tradition in Lamentations of the King James Bible (1611)}

The title of the book in the King James Bible (1611) is 'Lamentations of Ieremiah'. The English title of this book is taken from the Hebrew word qin̄ot 'lamentations', following the title used by the Septuagint (Threnoi Hieremiou 'Wailings of Jeremiah") and by the fourth century Latin Vulgate. The Hebrew Bible has the title $\hat{e} k \bar{a} h$ 'Ah, how' or 'Alas', the first word in the first, second, and fourth chapters; this word introduces the formula for the

McGrath, In the Beginning, 93-98.

14 Eliot, Prefaces and Prologues to Famous Books, 27-51.

15 Gray, The Book of Prefaces, 189-90.

16 DL Brake and S Beach, A Visual History of the King James Bible (Grand Rapids: Baker Books, 2011), 54; and Barnstone, The Poetics of Translation, 208.

17 Though approved by the Convocation of Canterbury, the Bishops' Bible apparently did not receive Elizabeth's authorization. 
commencement of a song of wailing. Jeremiah's authorship of Lamentations is deduced from 2 Chronicles 35:25: "Then Jeremiah chanted a lament for Josiah. And all the male and female singers speak about Josiah in their lamentations to this day. And they made them an ordinance in Israel; behold, they are also written in the Lamentations (qīnot).."

The position of Lamentations after Jeremiah in the King James Bible follows the tradition of the Septuagint and Vulgate versions. They placed it there because of its connection with the destruction of Jerusalem, which Jeremiah recorded, and the Jewish tradition that Jeremiah wrote both books. In the Hebrew Bible, Lamentations occurs between Ruth and Ecclesiastes as the third book of the Megilloth ('Scrolls') within the third and last major division of the canon, namely, 'Writings' ${ }^{18}$

In all copies of the Septuagint, whether of the Roman or Alexandrian editions, the

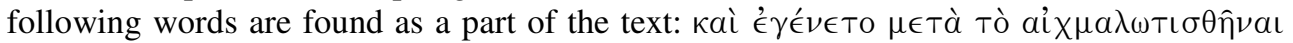

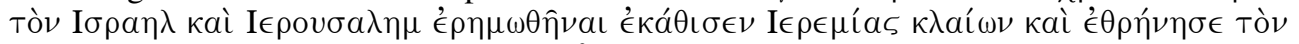

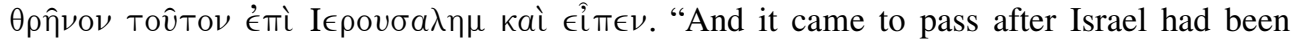
taken away into captivity and Jerusalem had been laid waste that Jeremiah sat weeping and lamented this lamentation over Jerusalem and said".

The Vulgate added, "with a bitter spirit sighing and wailing": Et factum est, postquam in captivitatem redactus est Israel, et Jerusalem deserta est, sedit Jeremias propheta flens, et planxit lamentatione hae in Jerusalem, et amaro animo suspirans et ejulans, dixit.

This tradition is repeated in the following four English translations. The translation of this section in the Vulgate is given in the first English printed translation of the Bible into English (Coverdale, 1535): "And it came to passe, (after Israel was brought in to captiuytie, and Ierusalem destroyed;) that Ieremy the prophet sat wepinge, mournynge, and makinge his mone in Ierusalem; so that wh an heuy herte he sighed \& sobbed, sayenge." The Great Bible (1540) refines this: "It happened after Israell was brought into captiuite, and Ierusalem destroyed, that Ieremy the prophete sate wepynge, and sorowfully bewayled Ierusalem and syghynge and howlynge with an heuy and wofull herte, sayde". The Matthew's Bible (1549) repeats: "It happened, after Israell was brought in to captyuytie \& Ierusalem destroyed, that Ieremy the Prophete sate wepynge, \& sorrowfully bewayled Ierusalem: and syghynge \& howlynge wyth an heuy and wofull herte, sayde:" A marginal note is added: "These words are reade in the lxx Intepreters but not in the hebreue". The translation in the Bishops Bible (1568) reads: "It happened after Israel was brought into captiuitie and Hierusalem destroyed, that Ieremie the prophete sate weepyng, and sorowfully bewayled Hierusalem, and sighing and howlyng with an heauy and wofull heart, sayde..." However, it is not repeated in the Geneva Bible (1560) or the King James Bible (1611).

\section{Innovations of KJV Lamentations in the Light of the English Translation Traditions \\ Updating of Language in the KJV}

There is evidence that the King James Bible updated the English language from the wording used in earlier translations. One example is from Lamentations 1:4. (Underlined words in the Geneva are replaced with contemporary words in the KJV.):

18 See GR Kotzé, "A Text-Critical Analysis of Lamentations 1:7 in 4QLam and the Masoretic Text," Old Testament Essays 24 (2011):590-611 concerning the textual tradition of the source text. 


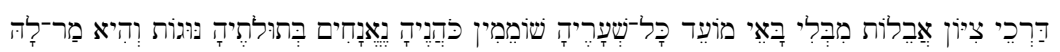

King James Bible: The ways of Zion do mourn, because none come to the solemn feasts: all her gates are desolate: her priests sigh, her virgins are afflicted, and she is in bitterness.

Geneva Bible: The wayes of Zion lament, because no man commeth to the solemne feastes: all her gates are desolate: her Priests sigh: her virgins are discomfited, and she is in heauinesse.

In translating the Hebrew נוגו as are discomfited,' the Geneva Bible replaces the translation tradition of 'are carefull' found in the Bishop's Bible, Matthew Bible, Great Bible, and Coverdale Bible. The KJV strengthens and updates the language to 'are afflicted.' In its use of 'heaviness' for פֵַ, the Geneva Bible continues the translation tradition of the Bishop's Bible ('great heauinesse'), Matthew's Bible ('greate heuynesse'), the Great Bible ('great heuynesse'), and the Coverdale Bible ('greate heuynesse'). The KJV updates the language to 'bitterness.'

Another example is found in Lamentations 3:11:

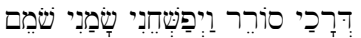

The Geneva Bible translates: "He hath stopped my wayes, and pulled me in pieces: he hath made me desolate." The KJV translates: "He hath turned aside my ways, and pulled me in pieces: he hath made me desolate." In translating 'turned aside,' the KJV continues the Geneva's attempt to update the language from the translation tradition of 'marred' which is found in the Bishop's Bible, Matthew Bible, Great Bible, and Coverdale Bible.

\section{KJV is Direct}

One of the most important translation strategies of the KJV is that of direct translation; the KJV attempts to represent the source text as much as possible to fulfil the aim to be an accurate translation. In this regard, the KJV sometimes does not follow the English translation tradition, especially that represented by its immediate predecessor, the Geneva Bible. For example, in Lamentations 2:2, the Hebrew uses the verb בְִּּ 'he swallowed' to describe God's action against Judah. The KJV translates directly ("The Lord hath swallowed up all the habitations of Jacob"), whereas the Geneva Bible is interpretive ("The Lord hath destroyed al the habitations of Iaakob"). ${ }^{19}$

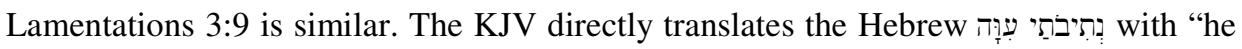
hath made my paths crooked" ("He hath inclosed my ways with hewn stone, he hath made my paths crooked"), whereas the Geneva is interpretative in translating "and turned away my paths" ("He hath stopped vp my wayes with hewen stone, and turned away my paths").

When the Hebrew uses figurative language, the KJV attempts to retain the Hebrew idiom, even when it involves going against the English translation tradition. In Lamentations 2:1, the Hebrew uses the idiom of covering with a cloud:

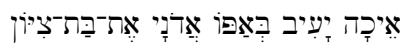

The KJV directly translates the Hebrew ("How hath the Lord covered the daughter of Zion with a cloud in his anger"), whereas the Geneva Bible followed the English translation

19 Contrast the Geneva rendering of the same verb in Lamentations 2:16 with "devour" alongside the KJV "swallow." 
tradition by changing 'cover with a cloud' to 'darkened,' which describes the result of cloud cover ("How hath the Lord darkened the daughter of Zion in his wrath!").

In contrast to the KJV's direct translation strategy, the Geneva often uses explicitation,

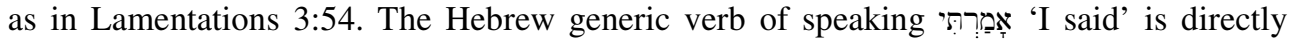
rendering by the KJV ("Waters flowed over mine head; then I said, I am cut off"), whereas the Geneva explicitates with 'thought I' to indicate that 'internal speech' is intended ("Waters flowed ouer mine head, then thought I, I am destroyed").

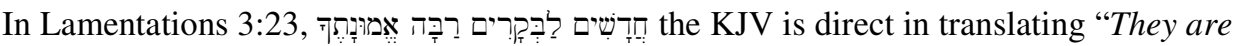
new every morning; great is thy faithfulness." The Geneva Bible uses explicitation in translating "They are renued euery morning; great is thy faithfulnesse." The Geneva Bible seems to be avoiding a theological misunderstanding that could arise from a direct translation: How can God's mercies be 'new' every morning if they are predestined?

The KJV's translation of the Hebrew נֶפּש is particularly interesting. Usually, the KJV follows a direct translation and renders the term with 'soul', as in Lamentations 2:12: “... when their soul was poured out into their mothers' bosom”. The Geneva translation reads: "... and when they gaue vp the ghost in their mothers bosome". However, the KJV follows the Geneva and translates with 'life' in places where 'soul' would have theological ramifications, as in Lamentations 5:9. The KJV reads: "We gat our bread with the peril of our lives because of the sword of the wilderness" and is similar to the Geneva translation: "Wee gate our bread with the perill of our liues, because of the sword of the wildernesse." A similar example is found in Lamentations 2:19, where both KJV and Geneva render "the life of thy young children". In one case in Lamentations, namely Lamentations 3:51 the KJV follows the Geneva in using 'heart' rather than 'soul' as a more natural English idiom, but places the direct translation of the Hebrew ('my soul') in a marginal note: "Mine eye affecteth mine heart because of all the daughters of my city." The marginal note reads: "mine heart: Heb. my soul". The Geneva Bible reads: "Mine eye breaketh mine heart because of all the daughters of my citie."

More frequently, the KJV translates directly in contrast to the Geneva Bible's use of an English idiom, as in Lamentations 1:21:

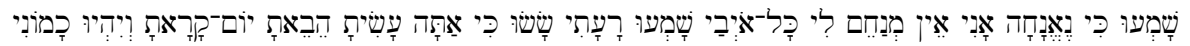

King James Bible: They have heard that I sigh: there is none to comfort me: all mine enemies have heard of my trouble; they are glad that thou hast done it: thou wilt bring the day that thou hast called, and they shall be like unto me. [Marginal note: called: or, proclaimed]

The Geneva Bible: They haue heard that I mourne, but there is none to comfort mee: all mine enemies haue heard of my trouble, and are glad, that thou hast done it: thou wilt bring the day, that thou hast pronounced, and they shalbe like vnto me.

Similarly, in Lamentations 1:22 (see also 5:17), the KJV translation is direct ("my heart is faint") as opposed to the Geneva Bible's use of an English idiom ("mine heart is heauy"):

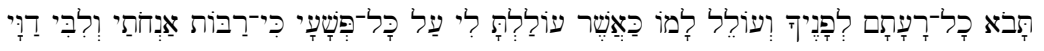

King James Bible: Let all their wickedness come before thee; and do unto them, as thou hast done unto me for all my transgressions: for my sighs are many, and my heart is faint.

The Geneva Bible: Let all their wickednes come before thee: do vnto them, as thou hast done vnto me, for all my transgressions: for my sighes are many, and mine heart is heauy. 


\section{KJV is Direct and Explicit; Geneva Bible is Euphemistic}

A particular kind of direct translation in the KJV involves the avoidance of euphemisms that are found in the Geneva Bible. In contrast with euphemistic renderings in the Geneva Bible, the KJV tends to use a direct and explicit translation strategy. For example, in

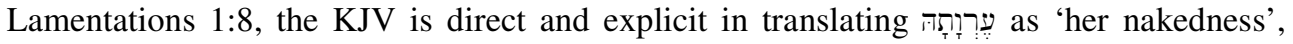
whereas the Geneva Bible translates 'her filthinesse.'

King James Bible: ....all that honoured her despise her, because they have seen her nakedness: yea, she sigheth, and turneth backward.

Geneva Bible: Ierusalem hath grieuously sinned, therefore shee is in derision: all that honoured her, despise her, because they haue seene her filthinesse: yea, she sigheth and turneth backeward.

As part of the move by the KJV to reflect the Hebrew more directly, earlier translation traditions are followed, in contrast to the Geneva Bible which follows a more euphemistic approach, as in Lamentations 5:11:

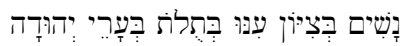

King James Bible: They ravished the women in Zion, and the maids in the cities of Judah.

Geneva Bible: They defiled the women in Zion, and the maydes in the cities of Iudah.

The KJV rendering follows that of the Bishop's Bible, the Matthew Bible, the Great Bible, and the Coverdale Bible.

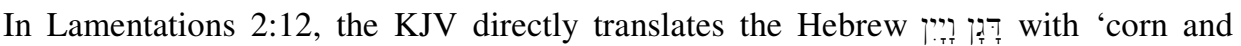
wine' ("They say to their mothers, Where is corn and wine? when they swooned as the wounded in the streets of the city") where the Geneva Bible has the euphemistic and less explicit 'bread and drinke' to avoid mentioning an alcoholic drink ("They haue sayd to their mothers, Where is bread and drinke? when they swooned as the wounded in the streetes of the citie").

Geneva Bible Translates within Religious Sphere; KJV Translates within General Sphere Although the KJV translators utilized the English language translation tradition to a large extent, in some cases the KJV prefers to use a term with a general meaning as opposed to the Geneva rendering with a term having a religious meaning. For example, in Lamentations $1: 2$, the KJV is a direct translation of the Hebrew general sphere 'have dealt treacherously' as opposed to the religious phrase 'have dealt unfaithfully' in Geneva.

The KJV regularly translates the Hebrew verb צִָָּּ directly as 'command', whereas the Geneva uses a variety of terms to convey its Calvinist theology. For example, in Lamentations 1:17, the KJV translates "the LORD hath commanded concerning Jacob, that his adversaries should be round around him." In contrast, the Geneva uses the theologically-laden term 'appoint' and translates: "the Lord hath appoynted the enemies of Iaakob rounde about him." In Lamentations 2:17, the KJV translates: "he hath fulfilled his word that he had commanded in the days of old." The Geneva has: "he hath fulfilled his worde that he had determined of old time."

Additional examples occur in the following verses. In Lamentations 1:10, the KJV 'congregation' is a direct translation of the Hebrew 


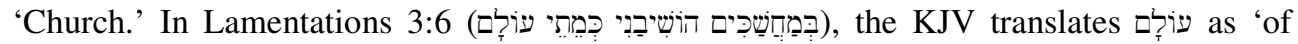
old' meaning that the individual is in a dark place like a tomb with dead corpses which were buried in antiquity ("He hath set me in dark places, as they that be dead of old."). Geneva translates 'for ever' meaning that the dead persons are eternally dead ("He hath set me in darke places, as they that be dead for euer").

\section{Geneva Bible Translates with Political Overtones; KJV Translates within General Sphere}

One translation strategy of the KJV is to use a neutral term in place of a term with policical overtones that is used in the Geneva Bible. For example, in Lamentations 1:7, the KJV replaces the political coloured rendering 'rebellion' from the Geneva Bible with the general term 'miseries':

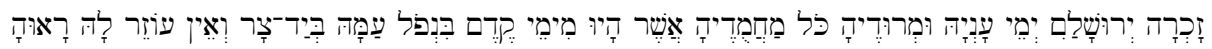

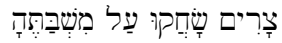

King James Bible: Jerusalem remembered in the days of her affliction and of her miseries all her pleasant things that she had in the days of old, when her people fell into the hand of the enemie, and none did helpe her: the adversaries saw her, and did mock at her sabbaths. [pleasant: or, desirable]

Geneva Bible: Ierusalem remembred the daies of her affliction, and of her rebellion, and all her pleasant things, that she had in times past, when her people fell into the hand of the enemie, and none did helpe her: the aduersarie sawe her, and did mocke at her Sabbaths.

\section{KJV has Idiosyncratic Translation; Geneva Bible has Direct Translation}

Occasionally, the KJV has an idiosyncratic translation. In Lamentations 3:36, the KJV uses a translation strategy of explicitation, but puts the direct translation in a marginal note. The Geneva Bible has a direct translation:

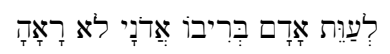

King James Bible: To subvert a man in his cause, the Lord approveth not. [Marginal note: approveth not: or, seeth not[

Geneva Bible: In subuerting a man in his cause: the Lord seeth it not.

In two verses in Lamentations (4:6 and 4:22), the KJV renders the noun עָ with 'punishment of iniquity,' which is combines both meanings of the word ('punishment' and 'iniquity'). In contrast, the Geneva Bible uses 'iniquitie' in 4:6 and 'punishment' in 4:22. In both verses, the KJV provides a marginal note with the direct translation 'iniquity'.

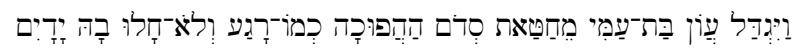

King James Bible Lamentations 4:6: For the punishment of the iniquity of the daughter of my people is greater than the punishment of the sin of Sodom, that was overthrown as in a moment, and no hands stayed on her. [punishment of the iniquity: or, iniquity]

Geneva Bible Lamentations 4:6: For the iniquitie of the daughter of my people is become greater then the sinne of Sodom, that was destroyed as in a moment, and none pitched campes against her.

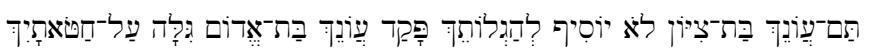

King James Bible Lamentations 4:22 The punishment of thine iniquity is accomplished, $\mathrm{O}$ daughter of Zion; he will no more carry thee away into captivity: he will visit thine 
iniquity, $\mathrm{O}$ daughter of Edom; he will discover thy sins. [Marginal notes: The...: or, Thine iniquity] [discover...: or, carry thee captive for thy sins]

Geneva Bible Lamentations 4:22 Thy punishment is accomplished, O daughter Zion: he will no more carie thee away into captiuitie, but he will visite thine iniquitie, $\mathrm{O}$ daughter Edom, he wil discouer thy sinnes.

In Lamentations 1:19, the KJV idiosyncratically renders the verb גוע with 'gave up the ghost' in contrast to 'perished' in the Geneva Bible. The usual KJV rendering for the verb is 'died' (see, for example, Genesis 6:17, 7:21; Numbers 17:27; 20:3, 20:29; Job 27:5, 29:18, 36:12; Psalm 88:15, 104:29; Zechariah 13:8) or 'perished' (Joshua 22:20; Job 34:15) except that it is rendered 'gave up the ghost' when it is used in conjunction with the verb מות 'die' (Genesis 25:8, 25:17, 35:29; Job 3:11).

\section{Illustration from Lamentations of the Anti-Marginal Note Policy of the King James Version as a Silencing Tool}

Another way in which the KJV translators mediated the religious conflict was to restrict the nature of the marginal notes. As explained in the preface entitled The Translators to the Reader, marginal notes were restricted to mainly three kinds: An asterisk in the text alerts the reader to cross references in the margin where related passages are indicated. A dagger in the text points to a note providing the Hebrew form of a word, the Hebrew meaning of a word or phrase, or the literal form of a Hebrew idiom underlying the translation. Parallel vertical bars point to some comment in the margin, which may explain a Hebrew unit of weight or measure, flag an ambiguity in the original text, present an alternative rendering of the original text, or propose an alternative reading for the original text.

The translators' position concerning marginal notes was a reaction especially to the numerous interpretive, polemical, antimonarchical, and devotional notes that cluttered the margins of the Puritans' Geneva Bible. But more importantly, this policy concerning restricting the metatextual material in marginal notes played a role in mediation between the viewpoints of the Anglicans and the Puritans. To illustrate the role of the presence or absence of marginal notes in restricting or opening up the interpretation of the biblical text, representative examples of the interplay between translated text and metatextual marginal note are examined with respect to central issues in the debate between Anglicans and Puritans - the king and the monarchy, church polity and Calvinistic theology. ${ }^{20}$

\section{The King and the Monarchy}

A central debate between Anglicans and Puritans involved the king and the role of the monarchy. The Geneva Bible used extensive marginal notes to highlight the Puritan perspective concerning the king. For example, in 1 Kings 12:9, the translation of the King James Version and the Geneva Bible are identical: ${ }^{21}$

20 The data for this analysis are drawn from the facsimile editions: The Holy Bible 1611 Edition King James Version (Peabody: Hendrickson, 2010); and The Geneva Bible: A Facsimile of the 1560 Edition (Peabody: Hendrickson, 2007)

21 Despite King James's rule that the Bishops' Bible be the guiding English translation, several phrases appear to be taken from the Geneva Bible for the King James translation. In some passages the King James Version emends the Bishops' version in favour of the Geneva Bible. 


\begin{tabular}{|l|l|l|l|}
\hline \multicolumn{1}{|l|}{ KJV } & Geneva & $\begin{array}{l}\text { Geneva marginal } \\
\text { note }\end{array}$ \\
\hline $12: 9$ & $\begin{array}{l}\text { And hee said vnto them, What } \\
\text { counsell giue ye, that we may } \\
\text { answere this people, who haue } \\
\text { spoken to mee, saying, Make the } \\
\text { yoke which thy father did put } \\
\text { vpon vs, lighter? }\end{array}$ & $\begin{array}{l}\text { And he said vnto them, } \\
\text { What counsel giue ye, } \\
\text { that we may answer } \\
\text { this people, which haue } \\
\text { spoken to me, saying, } \\
\text { Make the yoke, which } \\
\text { thy father did put vpon } \\
\text { vs lighter? }\end{array}$ & $\begin{array}{l}\text { There is no thing } \\
\text { harder for them, } \\
\text { that are in autoritie, } \\
\text { the to bridel their } \\
\text { affections and } \\
\text { followe good } \\
\text { counsel. }\end{array}$ \\
\hline
\end{tabular}

However, the Geneva Bible provides a marginal note that provides a critical assessment of the inability of "them, that are in authoritie" to "bridel their affections and followe good counsel." The King James Version translators accepted the wording of the Geneva Bible, but removed the marginal note, thus silencing the Puritans' overt criticism of the monarchy. The metatextual strategy of the King James Version translators is similar in Lamentations, as will be illustrated in the discussion that follows.

A general strategy of the Geneva marginal notes is to explicitate the referents of epithets and other descriptive expressions in the text. This also occurs with respect to verses involving the monarchy. In the following lament we can see how this metatextual strategy furthers the Geneva translators' negative view of the monarchy:

\begin{tabular}{|c|c|c|c|c|}
\hline & KJV & $\begin{array}{l}\text { KJV } \\
\text { note }\end{array}$ & Geneva & Geneva note \\
\hline $\begin{array}{l}\text { Lam } \\
4: 20\end{array}$ & $\begin{array}{l}\text { The *breath of our } \\
\text { nostrels, the anointed } \\
\text { of the Lord was taken } \\
\text { in their pits, of whom } \\
\text { we said, under his } \\
\text { shadowe we shall liue } \\
\text { among the heathen. }\end{array}$ & $\begin{array}{l}* \text { Gen } \\
2: 7\end{array}$ & $\begin{array}{l}\text { The breth of our } \\
\text { nostrels, the Anointed of } \\
\text { the Lord was taken in } \\
\text { their nets, of whome we } \\
\text { said, Vnder his shadowe } \\
\text { we shalbe preserued } \\
\text { aliue among the heathen. }\end{array}$ & $\begin{array}{l}\text { Our King Josiah, in } \\
\text { whome stode our hope of } \\
\text { Gods fauour, and on } \\
\text { whome depended our } \\
\text { state \& life, was slayne } \\
\text { whome he calleth } \\
\text { anointed, because he was } \\
\text { a figure of Christ. }\end{array}$ \\
\hline
\end{tabular}

The translation and interpretation of the term 'anointed' (Hebrew מִשיִָָ) also relates to the controversy concerning the monarchy, but with an additional theological twist - the term can also be interpreted christologically. By explicitating the referent of the anointed one by means of a marginal note, the Geneva translators make clear their theological understanding of the Christological significance of Josiah's death. By removing the marginal note, the King James translators refrain from explicitating the identity of the 'anointed one' even though it is not controversial or polemical (see, similarly, 1 Samuel 16:6 and Psalm 105:15 for additional examples of this metatextual strategy). They simultaneously refrain from engaging in theological specification of allegorical or figurative Christological interpretation.

Much less frequently, the King James Version translators added a marginal note where none is found in the Geneva Bible, as in Lamentations 5:16. 


\begin{tabular}{|l|l|l|l|}
\hline & KJV & KJV note & Geneva \\
\hline $\begin{array}{l}\text { Lam } \\
\text { 5:16 }\end{array}$ & $\begin{array}{l}\text { The crowne is fallen from our } \\
\text { head: Woe vnto vs, that wee } \\
\text { haue sinned. }\end{array}$ & $\begin{array}{l}\text { Hebr. The crowne } \\
\text { of our head is } \\
\text { fallen }\end{array}$ & $\begin{array}{l}\text { The crowne of our head is } \\
\text { fallen: wo now vnto vs, that } \\
\text { we haue sinned. }\end{array}$ \\
\hline
\end{tabular}

The King James Version adjusted the Hebrew idiom found in the Geneva Bible to a more natural English wording, but places the Geneva rendering in a marginal note.

At the beginning of the book, the Geneva Bible adds a marginal note to Lamentations 1:1 in order to explicate the way in which Judah, personified as a woman, was "great among the nations". The marginal note seems to promote an interpretation that the rule of Judah was empirical. By omitting the marginal note, the King James Version translators refrain from an explicit interpretation of the greatness of Judah on the international scene.

\begin{tabular}{|l|l|l|l|}
\hline & KJV & Geneva & Geneva note \\
\hline $\begin{array}{l}\text { Lam } \\
1: 1\end{array}$ & $\begin{array}{l}\text { She that was great among the nations, } \\
\text { and princesse among the prouinces, } \\
\text { how is she become tributarie? }\end{array}$ & $\begin{array}{l}\text { she that was great } \\
\text { among the nacions, and } \\
\text { princesse among the } \\
\text { prouinces, is made } \\
\text { tributarie }\end{array}$ & $\begin{array}{l}\text { Which had chief } \\
\text { rule over many } \\
\text { prouinces and } \\
\text { countreys. }\end{array}$ \\
\hline
\end{tabular}

In Lamentations 1:3, the Geneva translators added a marginal note to explicitate the reason given for Judah's captivity ("because of affliction and because of great servitude"). By using a cross reference to Jeremiah 34:11, the marginal note explains that their captivity is a result of their re-enslavement of their own servants after they had set them free. The Geneva marginal note thus seeks to narrow the interpretation of the verse to a particular historical occasion. The King James Version translators, although their rendering of the voice is identical to that of the Geneva, omit the marginal note, thus leaving the interpretation and identification of Judah's affliction and great servitude open.

\begin{tabular}{|l|l|l|l|l|}
\hline & KJV & $\begin{array}{l}\text { KJV } \\
\text { Note }\end{array}$ & Geneva & Geneva note \\
\hline $\begin{array}{l}\text { Lam } \\
1: 3\end{array}$ & $\begin{array}{l}\text { Iudah is gone } \\
\text { into captiuitie, } \\
\text { because of } \\
\text { affliction, and } \\
\text { because of great } \\
\text { seruitude: }\end{array}$ & $\begin{array}{l}\text { Heb, for the } \\
\text { greatnesse } \\
\text { of } \\
\text { seruitude. }\end{array}$ & $\begin{array}{l}\text { Iudah is caried } \\
\text { away captiue } \\
\text { because of } \\
\text { affliction, and } \\
\text { because of } \\
\text { great seruitude: }\end{array}$ & $\begin{array}{l}\text { For her crueltie toward the } \\
\text { poore and oppression of } \\
\text { seruants, Jerem. 34:11= But } \\
\text { afterwards they turned, and } \\
\text { caused the seruants and the } \\
\text { handmaids whom they had let } \\
\text { goe free, to returne, and } \\
\text { brought them into subiection } \\
\text { for seruants and for handmaids. }\end{array}$ \\
\hline
\end{tabular}

In Lamentations 1:6, the King James Version follows the Geneva's rendering. However, the Geneva marginal note explicitates the simile that Judah's princes have become "like harts that find no pasture and they are gone without strength before the pursuer". The marginal note seems unnecessary and redundant, but it emphasises that Judah's princes have behaved like ordinary men and not as special individuals who are part of the royal court. In this way, the Geneva marginal note highlights the ordinary, human nature of the monarchy. 


\begin{tabular}{|c|c|c|c|}
\hline & KJV & Geneva & Geneva marginal note \\
\hline Lam 1:6 & $\begin{array}{l}\text { And from the daughter of } \\
\text { Zion all her beautie is } \\
\text { departed: her princes are } \\
\text { become like Harts that } \\
\text { find no pasture, \& they } \\
\text { are gone without strength } \\
\text { before the pursuer. }\end{array}$ & $\begin{array}{l}\text { And from the daughter of } \\
\text { Zion all her beautie is } \\
\text { departed: her princes are } \\
\text { become }{ }^{\mathrm{h}} \text { like harts that finde } \\
\text { no pasture \& thei are gone } \\
\text { without strength before the } \\
\text { pursuer. }\end{array}$ & $\begin{array}{l}{ }^{\mathrm{h}} \text { As men pined away } \\
\text { with sorow \& that haue } \\
\text { no courage }\end{array}$ \\
\hline
\end{tabular}

In Lamentations 4:1, the King James Verson and the Geneva rendering are essentially identical. The Geneva marginal note explicitates the interpretation that the gold is not literal gold, but rather the princes. In this way, the Geneva Bible wishes to highlight its interpretation that the princes as part of the royal house have become ordinary people. By omitting this marginal note, the King James Version translators leave open the possibility of other interpretations of the verse. At the same time, the King James Version translators remove a marginal note which is negative toward the monarchy.

\begin{tabular}{|c|c|c|c|}
\hline & KJV & Geneva & Geneva marginal note \\
\hline Lam 4:1 & $\begin{array}{l}\text { How is the gold become } \\
\text { dimme! how is the most } \\
\text { fine gold changed! the } \\
\text { stones of the sanctuarie } \\
\text { are powred out in the top } \\
\text { of euery streete. }\end{array}$ & $\begin{array}{l}\text { How is the }{ }^{1} \text { golde become so } \\
\text { dimme? the most fine golde } \\
\text { is changed, and the stones of } \\
\text { the Sanctuarie are scattered } \\
\text { in the corner of euery streete. }\end{array}$ & $\begin{array}{l}{ }^{1} \text { By the golde he } \\
\text { meaneth the Princes, } \\
\text { as by te stones he } \\
\text { vnderstandeth the } \\
\text { Priests. }\end{array}$ \\
\hline
\end{tabular}

The marginal note strategy of the Geneva Bible continues in the following verse, Lamentations 4:2. In this verse, the rendering of the Geneva 'men of Zion' is interpretative and the direct translation ('sonnes', which is also followed by the King James Version) is provided in a marginal note. The Geneva marginal note again highlights that the comparison of the men of Zion to 'earthen pitchers' should be interpretated to mean that they are "of small estimation \& haue none honour." By omitting the marginal note, the King James Version translators leave open the connotation of 'earthen pitchers' as a simile for the 'precious sonnes of Zion' and avoid an explicitly negative viewpoint toward the elite individuals of ancient Judah.

\begin{tabular}{|c|c|c|c|}
\hline & KJV & Geneva & Geneva marginal note \\
\hline Lam 4:2 & $\begin{array}{l}\text { The precious sonnes of } \\
\text { Zion, comparable to fine } \\
\text { gold, how are they } \\
\text { esteemed as earthen } \\
\text { pitchers, the worke of the } \\
\text { hands of the potter! }\end{array}$ & $\begin{array}{l}\text { The noble }{ }^{1} \text { men of Zion } \\
\text { comparable to fine golde, } \\
\text { howe are they esteemed as } \\
\text { earthen }{ }^{2} \text { pitchers, euen the } \\
\text { worke of the handes of the } \\
\text { potter! }\end{array}$ & $\begin{array}{l}{ }^{1} \text { Or, sonnes } \\
{ }^{2} \text { Which are of small } \\
\text { estimation \& haue } \\
\text { none honour }\end{array}$ \\
\hline
\end{tabular}

By omitting the marginal notes that promoted a Puritan view of the monarchy and the royal court, the King James Version leaves open the interpretation of the text and silences the explicit condemnation of the monarchy found in the Geneva Bible. In so doing, the King James Version silences the metatextual explicitations and interpretations of the Geneva Bible as a means to allow a diversity of interpretations and characterizations. In this way, 
the King James Version could be used and appreciated both by Anglicans (who were loyal to the king) and Puritans (who were critical of the monarchy).

\section{Church Polity}

A second area which fuelled Puritan-Anglican controversy is church polity. ${ }^{22}$ The contrast in the interplay between text and metatextual marginal notes in the Geneva Bible and the corresponding silence in the King James Version is especially striking.

In Lamentations 1:10, the Geneva Bible uses 'Church' (in accordance with their translation brief) where the King James Version translators use 'congregation'. The marginal note of the Geneva Bible explicitates the identity of the 'heathen' who are forbidden entrance to the church, using a cross-reference to Deuteronomy 23:3. In this way, the Puritans reinforced their views concerning the exclusion from the church of 'enemies' who are metaphorically 'Ammonites \& Moabites.' Deuteronomy 23:3 was also used as a Calvinistic prooftext for predestination and limited atonement - just as God prevented Ammonites and Moabites from entering the congregation, so are others prevented from attaining salvation.

\begin{tabular}{|c|c|c|c|}
\hline & KJV & Geneva & Geneva marginal note \\
\hline $\begin{array}{l}\text { Lam } \\
1: 10\end{array}$ & $\begin{array}{l}\text { The aduersarie hath spread } \\
\text { out his hand vpon all her } \\
\text { pleasant things: for she hath } \\
\text { seene that the heathen } \\
\text { entred into her Sanctuarie, } \\
\text { whom thou didst command } \\
\text { that they should not enter } \\
\text { into thy congregation. }\end{array}$ & $\begin{array}{l}\text { The enemie hathe stretched } \\
\text { out his hande vpon al her } \\
\text { pleasant things: for she } \\
\text { hathe sene the heathen entre } \\
\text { into her Sanctuarie, whome } \\
\text { thou didest comande, that } \\
\text { they shulde not entre into } \\
\text { thy Church. }\end{array}$ & $\begin{array}{l}\text { God forbiddeth that } \\
\text { the Ammonites \& } \\
\text { Moabites shulde enter } \\
\text { into the Congregation } \\
\text { of the Lord, and vnder } \\
\text { the he coprehendeth } \\
\text { all enemies, Deu. } \\
23,3 \text {. }\end{array}$ \\
\hline
\end{tabular}

In Lamentations 1:15, the Geneva marginal note provides an alternative rendering of the difficult Hebrew text. This rendering is adopted in the King James Version text.

\begin{tabular}{|l|l|l|l|}
\hline & KJV & Geneva & Geneva marginal note \\
\hline $\begin{array}{l}\text { Lam } \\
1: 15\end{array}$ & $\begin{array}{l}\text { The Lord hath troden vnder } \\
\text { foot all my mightie men in } \\
\text { the midst of me: he hath } \\
\text { called an assembly against } \\
\text { mee, to crush my yong men. } \\
\text { The Lord hath troden the } \\
\text { virgine, the daughter of } \\
\text { Iudah, as in a wine presse. }\end{array}$ & $\begin{array}{l}\text { The Lord hathe troden vnder } \\
\text { fote all my valiant men in } \\
\text { the middes of me: he hathe } \\
\text { called an assembly against } \\
\text { me to destroy my yong men: } \\
\text { the Lord hath troden the } \\
\text { wine presse vpon the virgine } \\
\text { the daughter of Iudah. }\end{array}$ & $\begin{array}{l}\text { He hathe troden them } \\
\text { vnder fote as they } \\
\text { tread grapes in the } \\
\text { wyne presse. }\end{array}$ \\
\hline
\end{tabular}

In Lamentations 4:1 (discussed above in Section 5.1), the second part of the Geneva marginal note interprets the stones of the sanctuary as priests. By making this connection, the Geneva translators signal their negative viewpoint towards a religious hierarchy involving priests. In this way, they are implicitly critical of the Anglican church hierarchy.

22 JE Wehrmeyer, "Where Have All the Bishops Gone?" in JA Naudé (ed.), The Bible and Its Translations: Colonial and Postcolonial Encounters with the Indigenous. Bloemfontein: SUN MeDIA, 2009:106-29. 
By removing the marginal note, the King James Version translators open the interpretation of the verse and silence criticism directed at the Anglican church polity.

\begin{tabular}{|l|l|l|l|}
\hline & KJV & Geneva & Geneva marginal note \\
\hline $\begin{array}{l}\text { Lam } \\
4: 1\end{array}$ & $\begin{array}{l}\text { How is the gold become } \\
\text { dimme! how is the most } \\
\text { fine gold changed! the } \\
\text { stones of the sanctuarie } \\
\text { are powred out in the top } \\
\text { of euery streete. }\end{array}$ & $\begin{array}{l}\text { How is the }{ }^{1} \text { golde become so } \\
\text { dimme? the most fine golde } \\
\text { is changed, and the stones of } \\
\text { the Sanctuarie are scattered } \\
\text { in the corner of euery streete. }\end{array}$ & $\begin{array}{l}{ }^{1} \text { By the golde he } \\
\text { meaneth the Princes, } \\
\text { as by te stones he } \\
\text { vnderstandeth the } \\
\text { Priests. }\end{array}$ \\
\hline
\end{tabular}

\section{Puritan Theology}

The King James Version policy of suppressing interpretive marginal notes extended to instances in which the Geneva Bible used marginal notes to promote Puritan theology.

The Book of Lamentations provides numerous opportunities for the Geneva Bible translators to promote a Calvinistic view of suffering and repentance. For example, in Lamentations 5:21, the Geneva marginal note highlights God's agency in humans' conversion. Interestingly, while the King James translators refrain from including the content of the Geneva marginal note, they do retain the cross-reference to Jeremiah 31:18. In this way, they decline from an overt and explicit interpretation of the verse that supports Calvinistic theology.

\begin{tabular}{|l|l|l|l|l|}
\hline & KJV & $\begin{array}{l}\text { KJV } \\
\text { marginal note }\end{array}$ & Geneva & Geneva marginal note \\
\hline $\begin{array}{l}\text { Lam } \\
5: 21\end{array}$ & $\begin{array}{l}{ }^{1} \text { Turne thou vs } \\
\text { vnto thee, } \mathrm{O} \\
\text { Lord, and we } \\
\text { shall be turned: } \\
\text { renew our dayes } \\
\text { as of old. }\end{array}$ & ${ }^{1}$ Ier.31.18 & $\begin{array}{l}\text { Turne thou vs } \\
\text { vnto thee, O } \\
\text { Lord, and we } \\
\text { shalbe turned: } \\
\text { renue our } \\
\text { dayes as of } \\
\text { olde. }\end{array}$ & $\begin{array}{l}1 \text { Whereby is declared that it is } \\
\text { not in mans power to turne to } \\
\text { God, but is onely his worke to } \\
\text { conuert vs, and thus God } \\
\text { worketh in vs before we can } \\
\text { turne to him, Iere. 31. } 18 .\end{array}$ \\
\hline
\end{tabular}

In Lamentations 1:13, the Geneva marginal note provides an exhortation to the reader to acknowledge God as "the author al our afflictions, to the intent that we might seeke vnto him for remedy." The King James translators omit the marginal note and allow the reader to make an appropriate devotional or practical connection to the teaching of the verse.

\begin{tabular}{|c|c|c|c|}
\hline & KJV & Geneva & Geneva marginal note \\
\hline $\begin{array}{l}\text { Lam } \\
1: 13\end{array}$ & $\begin{array}{l}\text { From aboue hath he sent } \\
\text { fire into my bones, and it } \\
\text { preuaileth against them: he } \\
\text { hath spread a net for my } \\
\text { feete, he hath turned me } \\
\text { backe: he hath made me } \\
\text { desolate, and faint all the } \\
\text { day. }\end{array}$ & $\begin{array}{l}\text { From aboue hath }{ }^{1} \text { hee sent } \\
\text { fire into my bones, which } \\
\text { preuaile against them: he } \\
\text { hath spred a net for my } \\
\text { feete, and turned me backe: } \\
\text { hee hath made me desolate, } \\
\text { and daily in heauinesse. }\end{array}$ & $\begin{array}{l}{ }^{1} \text { This declareth that we } \\
\text { shoulde acknowledge } \\
\text { God to be the author of } \\
\text { al our afflictions, to the } \\
\text { intent that we might } \\
\text { seeke vnto him for } \\
\text { remedy. }\end{array}$ \\
\hline
\end{tabular}


In Lamentations 2:1, the Geneva Bible has three marginal notes. The first and second provide explanations of the metaphors used in the Hebrew. The third also explicates a metaphor, but is followed by an exhortation to the reader in the form of an indictment of ancient Israel for setting their minds 'so lowe' - they should rather "lift vp their hearts toward the heauens." The King James Version does not, as a rule, explicate the metaphors used in the source text; nor does it provide devotional exhortations for the reader on the basis of the source text.

\begin{tabular}{|c|c|c|c|}
\hline & KJV & Geneva & Geneva marginal notes \\
\hline $\begin{array}{l}\text { Lam } \\
2: 1\end{array}$ & $\begin{array}{l}\text { How hath the Lord } \\
\text { couered the daughter of } \\
\text { Zion with a cloud, in } \\
\text { his anger, and cast } \\
\text { downe from heauen } \\
\text { vnto the earth the } \\
\text { beautie of Israel, and } \\
\text { remembred not his } \\
\text { footstoole in the day of } \\
\text { his anger? }\end{array}$ & $\begin{array}{l}\text { Howe hath the Lord } \\
\text { darkened the daughter of } \\
\text { Zion in his wrath! and } \\
\text { hath cast downe from } \\
{ }^{2} \text { heauen vnto the earth } \\
\text { the beautie of Israel, and } \\
\text { remembred not his }{ }^{3} \\
\text { footestoole in the day of } \\
\text { his wrath! }\end{array}$ & $\begin{array}{l}\text { That is, brought her from } \\
\text { prosperitie to aduersitie. } \\
{ }^{2} \text { Hath giuen her a most sore } \\
\text { fall. } \\
{ }^{3} \text { Alluding to the Temple or to } \\
\text { the Arke of the couenant, which } \\
\text { was called the footestoole of } \\
\text { the Lord, because they shoulde } \\
\text { not set their mindes so lowe, } \\
\text { but lift vp their hearts toward } \\
\text { the heauens. }\end{array}$ \\
\hline
\end{tabular}

In Lamentations 3:8, the biblical verse describes God refusing to answer prayer. The Geneva marginal note provides an explanation of the verse and an exhortation to the reader to pray more earnestly.

\begin{tabular}{|l|l|l|l|}
\hline $\begin{array}{l}\text { Lam } \\
3: 8\end{array}$ & $\begin{array}{l}\text { KJV } \\
\text { Also when I cry and } \\
\text { my prayer. }\end{array}$ & $\begin{array}{l}\text { Geneva } \\
\text { Also when I cry and } \\
\text { showte, hee shutteth out } \\
\text { my prayer. }\end{array}$ & $\begin{array}{l}\text { Geneva marginal note } \\
\text { This is a great tentation to the } \\
\text { godly, when they see not the } \\
\text { fruite of their prayers, and } \\
\text { causeth them to thinke that they } \\
\text { are not heard, which thing God } \\
\text { vseth to doe, that they might pray } \\
\text { more earnestly and the oftener. }\end{array}$ \\
\hline
\end{tabular}

In Lamentations 3:22, the Geneva marginal note emphasises the Calvinistic doctrine of the perseverance of the saints.

\begin{tabular}{|c|c|c|c|}
\hline & KJV & Geneva & Geneva marginal note \\
\hline $\begin{array}{l}\text { La } \\
3: 22\end{array}$ & $\begin{array}{l}\text { It is of the Lords } \\
\text { mercies that wee are } \\
\text { not consumed, because } \\
\text { his compassions faile } \\
\text { not. }\end{array}$ & $\begin{array}{l}\text { It is the Lordes } \\
{ }^{1} \text { mercies that wee are } \\
\text { not consumed, because } \\
\text { his compassions faile } \\
\text { not. }\end{array}$ & $\begin{array}{l}{ }^{\mathrm{T}} \text { Considering the wickednes of } \\
\text { man, it is maruel tt any remaineth } \\
\text { aliue: but only that God for his } \\
\text { owne mercies sake \& for his } \\
\text { promes will euer haue his Church } \\
\text { to remaine though they be neuer } \\
\text { so fewe in nomber, Isa.1.9. }\end{array}$ \\
\hline
\end{tabular}

In Lamentations 3:27, the Geneva marginal note provides a devotional application of the verse, in accordance with Calvinistic theology. 


\begin{tabular}{|l|l|l|l|}
\hline & KJV & Geneva & Geneva marginal note \\
\hline $\begin{array}{l}\text { Lam } \\
3: 27\end{array}$ & $\begin{array}{l}\text { It is good for a man } \\
\text { that he beare the yoke } \\
\text { in his youth. }\end{array}$ & $\begin{array}{l}\text { It is good for a man } \\
\text { that he beare the } \\
\text { yoke in his 1 youth. }\end{array}$ & $\begin{array}{l}\text { ' He sheweth that we can neuer begin } \\
\text { too timely to be exercised vnder the } \\
\text { crosse, that when the afflictiōs grow } \\
\text { greater, iur patience also by } \\
\text { experience may be stronger. }\end{array}$ \\
\hline
\end{tabular}

In Lamentations 3:33, the Geneva marginal note re-iterates the content of the verse and adds the explicitation that God allows the wicked to oppress the poor.

\begin{tabular}{|c|c|c|c|c|}
\hline & KJV & $\begin{array}{l}\text { KJV marginal } \\
\text { note }\end{array}$ & Geneva & Geneva marginal notes \\
\hline $\begin{array}{l}\text { Lam } \\
3: 33\end{array}$ & $\begin{array}{l}\text { For he doth not } \\
\text { afflict } \\
1 \text { willingly, nor } \\
\text { grieue the } \\
\text { children of men. }\end{array}$ & $\begin{array}{l}{ }^{\mathrm{T}} \text { Heb. from his } \\
\text { heart. }\end{array}$ & $\begin{array}{l}\text { For he doeth not } \\
\text { punish } \\
{ }^{1} \text { willingly, nor } \\
\text { afflict the } \\
\text { children } \\
\text { of men, }\end{array}$ & $\begin{array}{l}{ }^{1} \text { He taketh no pleasure in it, } \\
\text { but doth it of necessitie for } \\
\text { our amēdement, when he } \\
\text { suffreth te wicked to } \\
\text { oppresse the poore } \\
{ }^{2} \text { Ebr. with his heart. }\end{array}$ \\
\hline
\end{tabular}

In Lamentations 4:22, the King James Version marginal notes provide alternative renderings based upon the Hebrew text. The Geneva marginal note, on the other hand, links the verse both to Jewish history and to Calvinistic theology of eternal perdition.

\begin{tabular}{|c|c|c|c|c|}
\hline & KJV & $\begin{array}{l}\text { KJV marginal } \\
\text { notes }\end{array}$ & Geneva & Geneva marginal note \\
\hline $\begin{array}{l}\text { Lam } \\
4: 22\end{array}$ & $\begin{array}{l}\text { The }{ }^{1} \text { punishment of } \\
\text { thine iniquitie is } \\
\text { accomplished, O } \\
\text { daughter of Zion, he } \\
\text { will no more carie } \\
\text { thee away into } \\
\text { captiuitie: hee will } \\
\text { visit thine iniquitie, O } \\
\text { daughter of Edom, } \\
\text { hee will }{ }^{2} \text { discouer thy } \\
\text { sinnes. }\end{array}$ & $\begin{array}{l}{ }^{1} \text { Or, thine } \\
\text { iniquitie. } \\
{ }^{2} \text { Or, carie thee } \\
\text { captiue for thy } \\
\text { sinnes }\end{array}$ & $\begin{array}{l}\text { Thy punishment is } \\
\text { accomplished, } \\
\text { O daughter Zion: } \\
\text { he }{ }^{1} \text { will no more } \\
\text { carie thee away } \\
\text { into captiuitie, but } \\
\text { he will visite thine } \\
\text { iniquitie, O } \\
\text { daughter Edom, he } \\
\text { wil discouer thy } \\
\text { sinnes. }\end{array}$ & $\begin{array}{l}{ }^{1} \text { He comforteth the } \\
\text { Church by that after } \\
\text { seuentie yeeres their } \\
\text { sorowes shal haue an } \\
\text { ende, whereas the } \\
\text { wicked should be } \\
\text { tormented for } \\
\text { euer. }\end{array}$ \\
\hline
\end{tabular}

We have seen that the Geneva Bible's marginal notes as metatexts served to regulate the reader's mental preparation to read the translated verses in accordance with the Puritan views concerning Calvinistic theology. The King James Version translators judiciously used marginal notes as metatexts in a highly restricted way. Often the marginal notes provide alternative readings or renderings of the source text which may support an alternative theological possibility but only rarely do the notes provide an overt theological or ideological interpretation. More frequently, the King James Version translators silenced the ideological marginal notes of the Geneva Bible, thus simultaneously opening up the translated verse to multiple interpretive possibilities while suppressing a distinctively Puritan ideological reading. 


\section{Conclusion}

The King James Version translators followed direct translation as an overall translation strategy, adopting the wording of previous English translations wherever possible and updating or revising them when necessary. In this way, they attempted to produce a translation that would be accepted because, on the one hand, it was accurate and, on the other hand, because it retained the well-known wording of previous English translations.

Another major goal of the King James Version was to mediate between the religious parties in England, especially the Anglicans and the Puritans, and to unite them around a single English translation. In this regard, the King James Version needed to find acceptance from both Anglicans and Puritans, with their differing views of the English throne, their different eccleciastical structures, and their divergent theological interpretations of the biblical text. By accepting much of the wording of the Geneva Bible, the King James translators produced a translation that would be acceptable to Puritans.

Apart from the text of the Geneva Bible, the marginal notes of that translation served as metatexts to regulate the reader's mental preparation to read the translated verses in accordance with the Puritan views concerning the king and the monarchy, ecclesiastical structure, and Calvinistic theology. In their anti-marginal policy the King James Version translators judiciously used marginal notes as metatexts in a highly restricted way. Often the marginal notes provide alternative readings or renderings of the source text which may support an alternative theological possibility but only rarely provide an overt theological or ideological interpretation. More frequently, the King James Version translators silenced the ideological marginal notes of the Geneva Bible, thus simultaneously opening up the translated verse to multiple interpretive possibilities while suppressing a distinctively Puritan ideological reading

By rejecting almost all of the Geneva Bible's metatextual marginal notes, however, the King James translators rejected sectarian interpretations of the biblical text and ensured that broader, non-sectarian interpretations would be considered orthodox. In this way, the King James Version succeeded in mediating religious conflict and uniting the opposing religious parties around a single translation of the Bible. The metatexts of the King James Version, far from being incidental to the ideology and goals from the King who commissioned its translation, are instead subtle but powerful means of mediation for advancing, achieving and implementing goals of political unity and theological harmony. 